\title{
PAULO FREIRE: UMA VIDA COMO OBRA QUE PERMANECE
}

\author{
Dulcinéia de Fátima Ferreira PEREIRA ${ }^{1}$
}

RESUMO: Este trabalho tem como objetivo revisitar Paulo Freire e apresentá-lo como uma obra que permanece. É fruto de uma metodologia que denominamos de "escavação da memória e escovação das palavras", inspirados em Boaventura de Souza Santos e no poeta Manoel de Barros. Procuramos compartilhar a sua caminhada pelo mundo e dialogar com a gênese do seu pensamento. Procuramos registrar elementos que pudessem nos auxiliar na compreensão do cenário vivido e na criação de novos modos de estar na educação e no mundo. Reafirmamos a atualidade da sua concepção político pedagógica no debate educacional contemporâneo, pois o seu pensamento traz germes da indignação, da rebeldia, da autonomia e da esperança. Suas palavras, quando escovadas, podem mobilizar, em nós educadores, o desejo de um mundo mais justo e uma educação mais humana. Revisitar Paulo Freire é um exercício encarnado em busca da liberdade.

Palavras-chave: Paulo Freire. Educação libertadora. Educação. Política.

\section{PRIMEIRAS PALAVRAS}

Neste trabalho revisitamos a vida e obra de Paulo Freire. Realizamos um trabalho de "escavação da memória e escovação das palavras", inspirados em Boaventura de Souza Santos (1996) e no poeta Manoel de Barros (2003). Para que o trabalho de "escavação na memória" fosse possível, realizamos uma pesquisa, como parte dos estudos de Doutorado sobre a gênese e o potencial do seu pensamento no campo da educação. Lançamo-nos no trabalho de "escovação das palavras" o que nos possibilitou pensar a vida de Paulo Freire como uma obra de arte que permanece, que ultrapassa barreiras, rompe o efêmero da vida humana.

Como uma obra de arte penetra em territórios invisíveis. Provoca-nos desassossegos, tira-nos do pedestal de tudo saber e tudo poder. Convida-nos a sermos sérios sem precisar ser sisudos. A diminuirmos a distância entre o que falamos e fazemos. A considerarmos as emoções e intuições como parceiras da razão. A ouvirmos os educandos, ao invés de só falarmos a eles. A acreditarmos que o outro também possui conhecimentos, mesmo que sejam diferentes do nosso, o acadêmico. Enfim, a

${ }^{1}$ UFSCAR - Universidade Federal de São Carlos - Campus Sorocaba - Departamento de Ciências Humanas e Educação. Líder do Grupo de pesquisa CNPq- Educação Comunidade e Movimentos Sociais (GECOMS). Sorocaba - SP - Brasil. 18052-780 - dulceferreira@ufascar.br 
vida de Paulo Freire como obra é um convite a todos nós a fazermos da nossa vida uma obra de arte.

Chamado por muitos de "andarilho da utopia" percorreu o mundo sempre desenvolvendo trabalhos que plantavam nos sentidos das pessoas a esperança e o desejo de um mundo melhor. Essa "andarilhagem" foi alimentada por vivências que se iniciaram nos seus tempos de menino.

Foi nesse experimentar-se no mundo, que recebeu influências de pessoas com as quais conviveu, tanto através de situações concretas como através de leituras e reflexões.

Não há como negar a sua maneira própria de pensar, porque reinventa e supera, em parte ou no todo, muitos dos seus mestres, a influência do marxismo, do existencialismo, do personalismo ou da fenomenologia. São presenças na sua leitura de mundo tanto Marx, Lukacs, Sartre e Mounier, quanto Albert Memmi, Erich Fromm, Franz Fanon, Merleau-Ponty, Antonio Gramsci, Karel Kosik, Marcuse, Agnes Heller, Simone Weill e Amilcar Cabral. (FREIRE, A., 1996, p.63).

É dentro deste fazer-se no mundo, que perguntas vão surgindo, aproximando-o de pessoas que como ele são obra. Uma necessidade de compreender melhor a vida para poder transformá-la movia sua ação no mundo, como foi o caso do seu encontro com Marx e Cristo.

Eu fui, na minha juventude, ao camponês e ao operário da minha cidade, movido pela minha opção cristã. Que eu não renego. Chegando lá, a dramaticidade existencial dos homens e mulheres com quem eu comecei a dialogar me remeteram a Marx [...] Eu fui a Marx por isso. E, indo a Marx, eu comecei a me surpreender com alegria por ter encontrado Marx entre os camponeses e entre os operários... Comecei a ver uma certa radicalidade original do pensamento marxista lá na área camponesa, de analfabetos. Então comecei, pensei, puxa, esse cara é sério! Não quero dizer que hoje sou um "expert" em Marx, ou que sou um marxista. Por uma questão até de humildade. Eu acho que é muito sério dizer que alguém é marxista. E a mesma coisa em relação à minha opção cristã. Eu sou um homem a procura de tornar-se um cristão. [...]

Em última análise, devo dizer que tanto a minha posição cristã quanto a minha aproximação a Marx, ambas jamais se deram ao nível intelectualista, mas sempre referidas ao concreto. Não fui às classes oprimidas por causa de Marx, fui a Marx por causa delas. O meu encontro com ela é que me fez encontrar Marx e não o contrário. (FREIRE, [s.d.] apud LEITE, 1979, p.74-75). 
Freire marcou a vida de muitas pessoas, bem como foi marcado por elas e, mesmo com toda grandiosidade da sua obra, todo o reconhecimento internacional, manteve-se humildemente como "pessoa", buscando sempre o diálogo com os outros e negando-se a ser transformado em mito. De acordo com Hurtado (1998), ao proferir uma conferência nos encontros, as pessoas tendiam a esquecer-se de que era um homem dialógico, então Freire precisava reafirmar: "Yo quiero ser coherente [...] y quiero ser um hombre de diálogo; por tanto, invito a todos los presentes a que dialoguemos, porque -insisto- yo no soy um mito y lucho contra mi própio mito." (HURTADO, 1998, p. 13).

Não compôs sua teoria

[...] para descrever e/ou prescrever o como fazer. Sua preocupação era ir à substantividade das coisas e dos fenômenos, perguntar, indagar, duvidar das certezas epistemológicas, histórica e ideologicamente consagradas, prontas e "imutáveis". Incentiva questionar sempre: Por quê? Contra quê? A favor de quê e de quem? (FREIRE, A. et al, 2001, p.28).

Até onde chegou ou até onde poderá chegar o pensamento de Freire não poderemos dizer, o que podemos é compartilhar como sua vida foi se transformando em obra num movimento permanente em busca da reinvenção do mundo, da recriação da vida.

\section{TRABALHO ARQUEOLÓGICO EM TORNO DA VIDA E OBRA DE PAULO}

\section{FREIRE}

Pois aqui está a minha vida. Pronta para ser usada. Vida que não se guarda nem se esquiva, assustada.

Vida sempre a serviço da vida.

Pra servir ao que vale a pena o preço do amor. Ainda que o gesto me doa, não encolho a mão: avanço levando um ramo de sol. Mesmo enrolada em pó, dentro da noite mais fria, a vida que vai comigo é fogo: está sempre acesa. (MELLO, 2002, p. 97).

Nascido em 19 de setembro de 1921, em Recife, bairro da casa Amarela. Freire foi se fazendo no mundo. No livro A importância do ato de ler, ele nos conta que foi no aconchego de sua família que aprendeu a traçar, com graveto no chão, as primeiras palavras. Nesse processo foi lendo o mundo ao seu redor. 
Me vejo então na casa mediana em que nasci, no Recife, rodeada de árvores, algumas delas como se fossem gente, tal a intimidade entre nós [...] A velha casa, seus quartos, seu corredor, seu sótão, seu terraço - o sítio das avencas de minha mãe -, o quintal amplo em que se achava, tudo isso foi o meu primeiro mundo. Nele engatinhei, balbuciei, me pus de pé, andei, falei. Na verdade aquele mundo especial se dava a mim como o mundo de minha atividade perceptiva, por isso mesmo como o mundo de minhas primeiras leituras. Os "textos", as "palavras", as "letras" daquele contexto - em cuja percepção me experimentava e, quanto mais o fazia, mais aumentava a capacidade de perceber - se encarnavam numa série de coisas, de objetos, de sinais, cuja compreensão eu ia apreendendo no meu trato com eles, nas minhas relações com meus irmãos mais velhos e com meus pais. (FREIRE, P., 1983, p.12-13).

Ainda pequeno, em meio à crise de 1929, sua família foi obrigada a deixar o Recife, indo morar em Jaboatão, município vizinho. Ele mesmo nos conta que lá perdeu seu pai e experimentou o que é a fome. "Em Jaboatão, quando tinha dez anos, comecei a pensar que no mundo muitas coisas não andavam bem. Embora fosse criança comecei a perguntar-me o que poderia fazer para ajudar aos homens." (FREIRE, P., 1980, p.14). Foi optando por estar ao lado dos "esfarrapados do mundo" (FREIRE, P., 1987).

Conforme Barreto (1998), Freire só conseguiu concluir seus estudos, graças a uma bolsa que sua mãe pleiteou junto ao, então diretor do Colégio Osvaldo Cruz, Dr. Aluízio Pessoa de Araújo. Colégio que retorna mais tarde como professor de Português, durante o tempo que cursava a faculdade de Direito.

Casou-se aos 23 anos, em 1944, com Elza, com quem, segundo ele dizia (FREIRE, P., 1980), prosseguiu o diálogo que aprendeu com os pais. Tiveram cinco filhos, três moças e dois meninos, com quem ampliaram a área dialogal.

Embora tenha concluído o curso de Direito, fez opção por não exercer a profissão. Ao abandonar a advocacia, começou a trabalhar no SESI como diretor do setor de Educação e Cultura. Nesta vivência os começam a germinar a concepção de educação libertadora, conscientizadora, dialógica e humanizadora.

Barreto (1998) nos conta que foi também nessa época que Freire aprendeu o quanto é diferente falar "com alguém" e falar "para alguém". Falar "com alguém" implicava uma relação horizontal, de respeito e trocas; um diálogo entre pessoas diferentes, porém não desiguais. Ao passo que "falar para alguém” implicava numa hierarquia na qual quem fala é o que sabe o que tem o poder, e o que escuta, nada sabe, nada pode além de escutar e concordar. 
Buscou no encontro com o outro a possibilidade de tecer novas relações de poder, de modo que a voz dos pais fosse ouvida assim como a dos técnicos já vinha sendo.

Paulo Freire 'viveu' as predisposições de modo inusitado e participativo. Não estava na moda falar-se de 'co-gestão'. Mas, no SESI, Paulo Freire iniciou a vivência de administrar "com", ultrapassando o "para", cujo conteúdo se associava a uma atitude benevolente do doador. (ROSAS, 2002, p. LX).

Em 1960, obteve o título de Doutor em Filosofia e História da Educação na então Universidade de Recife. Neste mesmo período, juntamente com outras pessoas, fundou e participou do Movimento de Cultura Popular de Recife (MCP)² e, em 1962, desenvolveu uma experiência em alfabetização de adultos na cidade de Angicos, no Rio Grande do Norte.

Preocupado com o papel político da educação e temendo que o trabalho com jovens e adultos se transformasse num processo de "invasão cultural", , Freire propôs "uma educação para a liberdade" a partir do "círculo de cultura"4. Em Angicos vai experienciando e registrando sua concepção político pedagógica. Aqui destacamos alguns aspectos:

2 “Os diversos relatos disponíveis sobre a criação do Movimento de Cultura Popular coincidem em afirmar que ele foi instituído sob a inspiração e o patrocínio direto da Prefeitura do Recife. Em maio de 1960, o então prefeito Miguel Arraes promoveu, apoiado em setores progressistas da intelectualidade e nos estudantes, a fundação do Movimento de Cultura Popular. Juridicamente nascia o MCP como uma sociedade civil autônoma. Suas atividades iniciais se orientaram, fundamentalmente, no sentido de conscientizar as massas através da alfabetização e educação de base. A realidade de um Estado com enorme índice de analfabetismo exigia esforços urgentes a fim de incorporar à sociedade os milhares de proletários e marginais do Recife, dotando-os de uma nova consciência. Com o tempo o MCP foi diversificando seu campo de ação, e novos tipos de contato com a massa se foram forjando: teatro, núcleos de cultura popular, meios informais de educação, canto, música e dança popular, artes plásticas e artesanato.” (BEISEGEL, 1989, p.119).

3 "Toda invasão sugere, obviamente, um sujeito que invade. Seu espaço histórico-cultural, que lhe dá visão de mundo, é o espaço de onde ele parte para penetrar em outro espaço histórico-cultural, superpondo aos indivíduos deste seu sistema de valores. O invasor reduz os homens do espaço invadido a meros objetivos de sua ação. As relações entre invasor e invadidos, que são relações autoritárias, situam seus pólos em relações antagônicas. O primeiro atua, os segundos têm a ilusão de que atuam na atuação do primeiro; este diz a palavra; os segundos, proibidos de dizer a sua, escutam a palavra do primeiro. $\mathrm{O}$ invasor pensa, na melhor das hipóteses sobre os segundos, jamais com eles; estes são pensados por aqueles. O invasor prescreve os invadidos são pacientes da prescrição.” (FREIRE, P., 1982, p. 41-42).

4 "Em lugar de professor, com tradições fortemente "doadoras", o Coordenador de Debates. Em lugar de aulas discursivas, o diálogo. Em lugar de aluno, com tradições passivas, o participante de grupo. Em lugar dos "pontos" e de programas alienados, programação compacta, "reduzida" e "codificada" em unidades de aprendizado." (FREIRE, P., 1980, p. 103). 
Do ponto de vista da libertação, o processo de alfabetização é um acto de conhecimento, um acto criador, no qual o iletrado, tanto como o seu instrutor, desempenha o papel de sujeito conhecedor. Os iletrados não são considerados como recipientes vazios ou como simples recipientes. Não são considerados como marginais que devem ser recuperados, mas como homens que estão impedidos de ler e de escrever pela sociedade na qual eles vivem, homens dominados, privados de seu direito de transformar o seu próprio mundo. (FREIRE, P., 1974, p.50).

Nesta experiência buscava superar a "Educação bancária"5 a partir de um processo de "conscientização"6. Recusando o uso das cartilhas, o processo de alfabetização era visto como possibilidade de "biografar-se, existenciar-se, historicizar-se" (FIORI, 1987).

Conforme Brandão (2001), o trabalho em Angicos, foi ganhando reconhecimento a ponto de o Governo Federal propor uma campanha nacional de alfabetização. No entanto, contrária à mobilização e participação popular, a elite dominante do país, vinha se articulando politicamente, com raízes profundas vinculadas aos interesses econômicos internos e externos.

Os últimos meses do ano de 1963 e os primeiros de 1964 se caracterizaram pela constante ameaça de golpes e contra-golpes. A radicalização política do período foi acompanhada por intensa mobilização dos diversos grupos políticos e já então se intensificara a conspiração de militares e elementos conservadores. Naquele momento, a multiplicação dos programas de alfabetização de adultos, secundada pela organização política das massas, aparecia como algo especialmente ameaçador aos grupos direitistas. (PAIVA, 1987, p.259).

${ }^{5}$ Educação bancária: "faz do processo educativo um acto permanente de depositar conteúdos. Acto no qual o depositante é o 'educador' e o depositário é o 'educando'. A concepção bancária, ao não superar a contradição educador-educando, mas, pelo contrário, ao enfatizá-la, não pode servir senão à 'domesticação' do homem. Da não superação dessa contradição decorre que o educador é sempre quem educa; o educando, o que é educado;

a) que o educador é quem disciplina; o educando, o disciplinado;

b) que o educador é o que fala; o educando, o que escuta;

c) que o educador prescreve; o educando, segue a prescrição;

d) que o educador escolhe o conteúdo do programa; o educando o recebe na forma de "depósito";

e) que o educador é sempre quem sabe; o educando, o que não sabe; que o educador é o sujeito do processo; o educando seu objeto." (FREIRE, P., 1974, p.14).

6 “A conscientização é um compromisso histórico. É também consciência histórica: é inserção crítica na história, implica que os homens assumam o papel de sujeitos que fazem e refazem o mundo. [...] A conscientização, como atitude crítica dos homens na história, não terminará jamais. [...] A conscientização nos convida a assumir uma posição utópica frente ao mundo, posição esta que converte o conscientizado em fator utópico." (FREIRE, P., 1980, p.27). 
Com o golpe militar, em 31 de março de 1964, projetos e movimentos tidos como de esquerda foram impedidos, pela repressão, de continuar atuando na sociedade. Freire considerado uma ameaça à ordem e ao progresso do país. Como podemos ver:

Fui considerado como um "subversivo internacional", um "traidor de Cristo e do povo brasileiro". "Nega o senhor - perguntava um dos juizes - que seu método é semelhante ao de Stalin, Hitler, Perón e Mussolini? Nega o senhor que com o seu pretendido método o que quer é tornar bolchevique o país?... (FREIRE, P., 1980, p. 16).

E segue dizendo:

É claro que havia um mínimo de condições objetivas para que eles pudessem fazer estas acusações. A fundamentação básica para que eu fosse chamado de comunista eu dava. Eu pregava uma pedagogia desveladora das injustiças; desocultadora da mentira ideológica. Dizia que o trabalhador, enquanto educando, tinha o dever de brigar pelo direito de participar da escolha dos conteúdos ensinados a ele. Eu defendia uma pedagogia democrática que partia das ansiedades, dos desejos, dos sonhos, das carências das classes populares. (FREIRE apud BARRETO, 1998, p. 29).

Enquanto a ditadura se instalava no Brasil Freire foi impedido de continuar seu trabalho e exilado. Obrigado a deixar sua terra, sua gente, vive com a dor da saudade um "alvoroço na alma" (FREIRE, P., 1992), um sentimento de ser "partido ao meio" (CALVINO, 2002).

Esta experiência de viver o exílio lhe possibilitou novos aprendizados. Aprendeu a lidar com a saudade sem permitir que ela virasse nostalgia. Não se entregou ao desânimo, mas aprendeu a curar sua dor ajudando outros que sofriam.

Passando pela América Latina, África e Europa, experimentou situações que foram lhe provocando novas reflexões. Foi reafirmando sua concepção de educação. Assim nasceu a Pedagogia do oprimido.

Recusando-se a acomodar-se ao estilo das grandes narrativas, a "Pedagogia do Oprimido" foi o começo e a mais famosa obra de um corpo de trabalho sempre inquieto e inquietante, impaciente e ao mesmo tempo engajado. Diferente da prosa acadêmica e pública, politicamente árida e moralmente vazia que caracteriza os discursos intelectuais contemporâneos, o trabalho de Freire era consistentemente impelido por uma raiva saudável da opressão e do sofrimento desnecessários que ele testemunhou por toda parte durante a sua vida. (GIROUX, 2001, p.116). 
Enquanto a ditadura imprimia marcas na nossa história, Freire sofreu críticas da direita, sendo tachado de comunista, marxista e considerado, como já foi dito, uma ameaça à ordem interna. Ao mesmo tempo, duros questionamentos lhe foram dirigidos por parte da esquerda, por ser considerado um reformador e cristão.

Para alguns Freire era um subversivo, revolucionário, expoente da esquerda radical, submetido como tal, à prisão e ao exílio, sendo associado por muitos ao marxismo, ao socialismo e até ao comunismo. Para outros, um educador apolítico, um tíbio "humanista culturalista", um ideólogo da conscientização, sem uma proposta política de genuína transformação social. Para outros um pensamento incompleto, com falta de rigor científico, que necessitava de elaboração teórica, que continuou a repetir-se a si mesmo e perdeu atualidade. (TORRES, 2001, p. 233).

Enquanto no Brasil as críticas se desdobraram de várias maneiras, como tentativa de abandono e silenciamento de sua obra, fora do país,

[...] desabrochou e ganhou renome mundial, tornando-se referência obrigatória quando se fala de alfabetização, educação de adultos, educação popular ou comunitária. Pode-se estar de acordo ou não com o seus pontos de vista; contudo é impossível ignorar a sua obra. (REGIS, 2000, p.70).

O Final da década de 60 e os anos 70 foram duros. Os militares usavam da força para controlar a situação. No entanto "Tudo racha e estala como no equipamento de um veleiro destroçado. [...] Ao lado do poder, há sempre a potência. Ao lado da dominação, há sempre a insubordinação.” (PELBART, 2010, p.42-43).

Mesmo diante da dura repressão muitos se engajaram em movimentos clandestinos de resistência e, nos anos 80, a mobilização popular explode por todo país.

É a década, sem dúvida, de maior participação cidadã no país. Os "novos personagens" rompem a cena e exigem direitos, inclusão no contrato social, alargamento dos direitos de cidadania, sejam políticos, sociais, econômicos ou culturais. O movimento sindical combativo que cria, em 83, a Central Única dos Trabalhadores (CUT), os movimentos populares que fundam a Central dos Movimentos Populares, os trabalhadores Rurais Sem Terra, que constituem o MST em 1985, e o movimento político que cria ou reconstrói, partidos de esquerda, particularmente o PT. [...] Em 1984 o país assiste ao chamado "Movimento das Diretas Já", que leva às ruas e praças milhões de pessoas reivindicando o direito básico de poder votar para Presidente da República. Esse grande movimento emancipatório [...] obtém a redemocratização do país e consolida seus direitos de cidadania na constituição de 1988. (PEREIRA, 2003, p.4-5). 
Aqueles que sonhavam com um mundo mais justo levantaram a bandeira da necessidade de democratização do país e, deste modo, as lutas populares conquistam a anistia para os presos políticos. Em 1980, Paulo Freire pôde voltar ao Brasil depois de 16 anos de exílio.

Ao retornar Freire, já bem maduro, com seus 58 anos de idade, aponta a necessidade de recriarmos o mundo tendo como motor da transformação a esperança.

Afirma:

Não sou esperançoso por pura teimosia, mas por imperativo existencial e histórico. Não quero dizer, porém, que, porque esperançoso, atribuo à minha esperança o poder de transformar a realidade e, assim convencido, parto para o embate sem levar em consideração os dados concretos, materiais afirmando que minha esperança basta. (FREIRE, P., 1992, p.10).

E segue dizendo...

Pensar que a esperança sozinha transforma o mundo e atuar movido por tal ingenuidade é um modo excelente de tombar na desesperança, no pessimismo, no fatalismo. [...] Enquanto necessidade ontológica a esperança precisa da prática para tornar-se concretude histórica. É por isso que não há esperança na pura espera, nem tampouco se alcança o que se espera na espera vã.

Sem um mínimo de esperança não podemos sequer começar o embate, mas sem o embate, a esperança como necessidade ontológica, se desarvora, se desendereça e se torna desesperança que, às vezes, se alonga em trágico desespero. Daí a precisão de uma certa educação da esperança. (FREIRE, P., 1992, p.10).

A sua crença na vida e no homem faz com que retorne ao Brasil disposto, também a recomeçar, a continuar a lapidação da sua vida como obra. Como militante engajou-se na criação do Partido dos Trabalhadores, do qual participou como um dos membros fundadores.

"Essa capacidade de começar sempre, de fazer, de reconstruir, de não se entregar, de recusar burocratizar-se mentalmente, de entender e de viver a vida como processo, como vir-a-ser, é algo, que sempre me acompanhou ao longo dos anos." (FREIRE, P., 1995, p.103).

Em 1986 sofre uma grande tristeza. Perde Elza sua primeira mulher. “Todos os que testemunharam o carinho e o respeito mútuo que havia entre os dois acreditavam 
que seria muito difícil para ele superar perda tão grande. Muitos são os relatos que podemos encontrar sobre este período de sua vida." (BARRETO, 1998, p. 25).

Mais uma vez, com a dor de quem é "partido ao meio", o amor à vida vence a dor da morte e vai retomando suas atividades. Uma das atividades que realizava neste período, na PUC-SP, era a de professor-orientador de Ana Maria Araújo Hasche. "Ana Maria era, coincidentemente, uma das filhas do diretor de escola que, muitos anos antes, havia dado a Paulo a oportunidade de continuar seus estudos." (BARRETO, 1998, p.44). Durante as orientações, uma mudança na relação entre eles foi se dando, de amigos a amores: "Nossa relação ganhou um novo significado: "mudamos a natureza de nossa relação.” (FREIRE, A., 2005, p.18). Casaram-se em 27 de março de 1988.

Em 1989, o PT vence as eleições municipais em São Paulo, elegendo como prefeita Luíza Erundina. Certa de que o "nome" de Freire representa os anseios de educadores e daqueles que a elegeram, convida-o para assumir a Secretaria Municipal de Educação de São Paulo. Comprometido com o processo de democratização do país aceita o convite.

Aceitei o convite que a Erundina me fez porque eu não tinha o direito de dizer não depois de toda a vida que tinha vivido, depois das denúncias que fiz, de ter escrito o que escrevi. Para dizer não, teria que tirar os livros que escrevi do prelo e não escrever mais. Era um preço muito caro. Eu precisava continuar escrevendo e falando. (FREIRE apud BARRETO, 1998, p. 46).

Ao assumir a SME de São Paulo, engajou-se na luta por reinventar a escola pública. Sabendo das dificuldades de se transformar estruturas historicamente enrijecidas seguiu afirmando:

[...] a escola pública que desejo é a escola onde tem lugar de destaque a apreensão crítica do conhecimento significativo através da relação dialógica. É a escola que estimula o aluno a perguntar, a criticar, a criar; onde se propõe a construção do conhecimento coletivo, articulando o saber popular e o saber científico, mediados pelas experiências no mundo. (FREIRE apud BARRETO, 1998, p. 46).

Dentre as diversas ações, deste período, destacamos a criação do $\mathrm{MOVA}^{7}$ (Movimento de Alfabetização de Jovens e Adultos) “[...] a partir de sua compreensão de

7 [...] Na realidade, o Mova inaugurou um novo tipo de educação popular, de educação de adultos, no qual dialeticamente se envolvem alfabetizandos / comunidade / poder estatal organizado. O Mova-SP tornou-se modelo de educação popular e de alfabetização de adultos para muitas das secretarias 
educação popular de alfabetização e pós-alfabetização ético-político-ideológicoepistemológica." (FREIRE, A., 2005, p.23).

Sua gestão foi um permanente exercício de diálogo com os educadores, funcionários, pais e educandos. Experimentou o pensar, o decidir e o fazer com os outros, uma forma de gestão democrática e participativa, propondo a descentralização da administração da SME e trabalhos coletivos que envolvessem toda comunidade escolar. Desejava mudar a "cara" da escola sobre esta questão afirmava:

Precisamos demonstrar que respeitamos as crianças, suas professoras, sua escola, seus pais, sua comunidade; que respeitamos a coisa pública, tratando-a com decência. [...] Neste sentido é que reparar rapidamente as escolas é já mudar um pouco sua cara, não só do ponto de vista material mas, sobretudo, de sua "alma". Precisamos deixar claro que acreditamos em quem e respeitamos quem se acha nas bases. [...] Mudar a cara da escola implicava em ouvir meninos e meninas, sociedade de bairro, pais, mães, diretoras de escola, delegados de ensino, professoras, supervisoras, comunidade científica, zeladores, merendeiras, etc. Não se muda a cara da escola por um ato de vontade do Secretário (FREIRE, P., 1995, p.34-5).

Para Paulo Freire (1995), mudar o jeito da educação se realizar era uma das tarefas políticas da gestão para que no futuro outros sonhos que pareciam impossíveis pudessem também se realizar. Sabia-se que a educação não era a chave para a transformação do mundo, mas que sem ela a mudança não poderia ocorrer.

Por mais de dois anos permaneceu à frente da SME de São Paulo. Lutou, discutiu sobre a educação que sonhava implementar, dialogou com as crianças e os educadores, funcionários, pais e mães, técnicos da educação. Após este período decide retornar à prática docente, bem como aos seus textos, pois entende que sua colaboração poderia se dar de outra forma.

Em uma solenidade, Freire se despediu de todos e todas que junto com ele atuaram na Secretaria, com os seguintes dizeres:

Não estou, rigorosamente, saindo da Secretaria Municipal de Educação ou mesmo deixando a companhia de vocês. Nem tampouco renegando opções políticas e ideológicas antigas, anteriores mesmo à criação do PT. Não imaginava sequer que o PT aconteceria, na minha juventude, mas sentia muita falta de sua existência. Esperei por mais de quarenta anos que o PT fosse criado.

municipais de educação de governos progressistas e outras instituições educativas, embora, infelizmente, algumas vezes com distorções que são, ingênua ou manhosamente, ditas como recriação freireana. (FREIRE, A., 2005, p. 23). 
Mesmo sem ser mais secretário, continuarei junto de vocês, de outra forma. Vou mais livre para assumir outro tipo de presença.

Não estou deixando a luta, mas mudando, simplesmente, de frente. A briga continua a mesma. Onde quer que esteja estarei me empenhando, como vocês, em favor da escola pública, popular e democrática.

Continuem contando comigo na construção de uma política educacional, de uma escola com outra "cara", mais alegre, fraterna e democrática. (FREIRE, P., 1995, p.143-144).

Retornou à docência na PUC de São Paulo, com seu trabalho cotidiano de orientação e produção de textos. Casali (1998, p.108) chama este período de trabalho artesanal: "O trabalho artesanal de escrita de novos livros, como Pedagogia da Esperança, como Professora sim, Tia Não, como A educação na cidade, como Cartas a Cristina, e depois À sombra dessa mangueira e Pedagogia da Autonomia."

Durante os anos 90, o neoliberalismo ganha força mundial, como uma nova face do capitalismo. Acontecimentos internacionais são divulgados pela mídia ${ }^{8}$ na tentativa de enfraquecer as organizações e movimentos populares. As consequências desta globalização sobre o humano são perversas se alastram com rapidez. Durante os anos 1980 e 1990, Freire denunciou:

Nenhuma realidade é porque tem que ser. A realidade pode e deve ser mutável, deve ser transformável. Mas, para justificar os interesses que obstaculizam a mudança, é preciso dizer que "é assim mesmo". O discurso da impossibilidade é, portanto, um discurso ideológico e reacionário. Para confrontar o discurso ideológico da impossibilidade de mudar tem-se de fazer um discurso também ideológico de que pode mudar. Eu não aceito, eu recuso completamente essa afirmação, profundamente pessimista, de que não é possível mudar. (FREIRE et al, 2001, p. 169).

Afirmando esperançosamente que podemos interferir nos rumos da História, Paulo Freire, o "andarilho da utopia" não se cansa e reafirma em diversos de seus livros que não podemos existir sem sonhos, sem ter pelo que lutar.

Os 75 anos modificaram um pouco a resistência do meu corpo: por exemplo, subir dois andares sem elevador já começa a ser um problema. Mas os 75 anos não diminuíram em nada a vontade de viver, a capacidade de amar o mundo, o gosto pela briga em favor da

8 “O mundo assistiu à derrubada do muro de Berlim (1989), e ao acaso do leste europeu, transformando o mundo bipolarizado da guerra fria, num mundo unipolar sob o domínio dos Estados Unidos". (PEREIRA, 2001, p. 25). Pudemos ver também o ataque às torres gêmeas de NYC, em 11/09/2001, além de tantos outros acontecimentos que nos afetaram. 
transformação do mundo, a esperança, o otimismo na luta do dia a dia, a curiosidade. Tudo isso se intensificou e se aprofundou em lugar de desaparecer. (FREIRE, P., 2004, p.145).

Homem maduro, vivido, sensível, sobretudo amoroso e esperançoso, resistiu aos discursos fatalistas de que a história chegara ao final, denunciou e anunciou até o final da sua vida.

O que me parece impossível aceitar é não haver outro caminho para as economias frágeis senão acomodar-se pacientemente, ao controle e aos ditames do poder globalizante. Poder ante o qual não há como não nos curvar fatalisticamente, de braços cruzados, estupefatos ou conformados. O que me parece impossível é silenciar diante dessa expressão pós-moderna de autoritarismo. O que me parece impossível é aceitar docilmente que o mundo mudou radical e repentinamente, da noite para o dia, fazendo sumir as classes sociais, esquerda e direita, dominadores e dominados, acabando com as ideologias e tornando tudo mais ou menos igual. [...] Veementemente, contudo, recuso aceitar que eu "já era" porque continuo reconhecendo a existência das classes sociais, porque nego a ideologia da despolitização da administração pública, embutida na chamada "política de resultados", porque afirmo a força das ideologias (FREIRE, P., 2000, p.49).

A Pedagogia defendida por Freire, durante toda sua vida e reafirmada nesta década, está cheia de compromisso político, sonhos e esperança. Para ele, ser utópico ou sonhador, não é ser idealista ou algo impraticável, mas estar comprometido com uma constante denúncia de realidade desumana e anúncio de sua possibilidade de transformação.

Semblante calmo, cabelos longos e barbas brancas, estatura mediana, corpo magro, olhos cor de mel e sua constante disposição para trocar experiências, para dialogar, sobretudo quando está explicando suas ideias sobre educação ou discutindo as de outros, são algumas de suas características marcantes. São igualmente significativos seu olhar forte, meigo, profundo, comunicante e os gestos, sempre expressivos, de suas mãos. O olhar e os movimentos das mãos revelam os desejos e os espantos de sua alma eternamente apaixonada pela vida. Quem conheceu Freire dificilmente se esquecerá destes traços que traduzem sua personalidade segura, terna e comunicativa. (FREIRE, A., 1996, p.67).

Esse foi Paulo Freire. Seus gestos, suas palavras, sua experiência nos convidam a assumirmos o nosso papel de sujeitos da história, diante da "dramaticidade da hora atual". (FREIRE, P., 1987). 


\begin{abstract}
Às margens de outro mar, outro oleiro se aposenta em sua idade avançada. Seus olhos ficam embaçados, suas mãos tremem, chegou para ele a hora do adeus. Então ocorre a cerimônia da iniciação: o oleiro velho oferece ao oleiro jovem sua melhor peça. Assim manda a tradição entre os índios do noroeste da América: o artista que se despede entrega a sua obra-prima ao artista que se inicia. E o oleiro jovem não guarda esta vasilha perfeita para contemplá-la e admirá-la, senão que a estala contra o solo, a rompe em mil pedacinhos, recolhe os pedacinhos e os mistura em sua argila. (GALEANO, 1993, p.86).
\end{abstract}

Frente a finitude humana, no dia 2 de maio de 1997, ele se despede de nós. Deixa a mensagem que "gostaria de ser lembrado como um sujeito que amou profundamente o mundo e as pessoas, os bichos, as árvores, as águas, a vida”. (FREIRE, P., 2004, p.329). Ficam suas palavras e o exemplo de vida ... podemos misturá-las em nossas “argilas” ...

\title{
CONSIDERAÇÕES FINAIS
}

Ao realizarmos este trabalho de escavação e escovação podemos reafirmar que a vida de Freire é uma obra que permanece. Nosso desejo é continuar sua andarilhagem pelo mundo resistindo à lógica do capital que insiste em transformar a nossa vida em uma mercadoria. Desejamos fazer da vida uma obra de arte re-existindo, criando outros modos de estar na educação.

Com Freire aprendemos que não é necessário cartilha e nem pacotes pedagógicos, vendidos nas prateleiras enganosas da lógica neoliberal, mas sim “[...] inventar o possível, ocupar um espaço de movimentação onde possa surgir uma liberdade." (CERTEAU, 2012, p.14). Este trabalho de “escavação" e "escovação" é sinal de que estamos caminhando nesta direção.

\section{PAULO FREIRE: A LIFE AS A WORK THAT REMAINS}

$\overline{\text { ABSTRACT: This work has as objective revisit Paulo Freire and present him as a work }}$ that remains. It is the result of a methodology that is named as "digging the memories and brushing the words", inspired in Boaventura de Souza Santos and in the poet Manoel de Barros. We looked to share his journey around the world and dialog with his thoughts genesis. We build on registering the elements that could assist on the comprehension of the lived scenario and the creation of new ways of being inside the education and in the world. We restate the political and pedagogical conception on the contemporary educational debate, because his thoughts brings germs of resentment, refractoriness, autonomy and hope. His words, when brushed, can mobilize, on us 
educators, the desire of a fairer world and an education more human. Revisit Paulo Freire is an exercise of the quest for freedom.

KEY-WORDS: Paulo Freire. Liberating education. Education. Politics.

\section{REFERÊNCIAS}

BARRETO, V. Paulo Freire para educadores. São Paulo: Arte e Ciência, 1998.

BARROS, M. Memórias inventadas: a infância. São Paulo: Planeta, 2003.

BEISIEGEL, C. R. Política e educação popular: a teoria e a prática de Paulo Freire no Brasil. São Paulo: Ática, 1989.

BRANDÃO, C. R. História do menino que lia o mundo. 3.ed. Veranópolis, RS: ITERRA, 2001.

CALVINO, Í. O visconde partido ao meio. São Paulo: Companhia das Letras, 2002.

CASALI, A. Paulo Freire: o educador na história. Revista Educação, Sociedade e Culturas, Porto, n.10, p.95-109, out. 1998.

CERTEAU, M. A cultura no plural. 7.ed. Campinas: Papirus, 2012.

FIORI, E. M. Aprender a dizer a sua palavra. [Prefácio]. In: FREIRE, P. Pedagogia do oprimido. 17.ed. Rio de Janeiro: Paz e Terra, 1987. p.2-30.

FREIRE, A. M. A. Utopia peregrina. Revista Memória da Pedagogia, São Paulo, v.4, p.16-29, 2005.

A voz da esposa: a trajetória de Paulo Freire. In: GADOTTI, M. et al. Paulo Freire: uma biobibliografia. São Paulo: Cortez, 1996. p.24-67.

FREIRE, A. M. A. et al. Pedagogia da libertação em Paulo Freire. São Paulo: Ed. da UNESP, 2001.

FREIRE, P. Pedagogia da tolerância. São Paulo: Ed. da UNESP, 2004.

Pedagogia da indignação: cartas pedagógicas e outros escritos. São Paulo: Ed. da UNESP, 2000.

Pedagogia da esperança: um encontro com a pedagogia do oprimido.

3.ed. São Paulo: Paz e Terra, 1992.

Educação na cidade. 2.ed. São Paulo: Cortez, 1995.

Pedagogia do oprimido. 17.ed. Rio de Janeiro: Paz e Terra, 1987.

A importância do ato de ler: em três artigos que se completam. São

Paulo: Cortez, 1983. 
. Extensão ou comunicação? 6.ed. Rio de Janeiro: Paz e Terra, 1982.

. Conscientização: teoria e prática da libertação. São Paulo: Moraes, 1980.

Uma educação para a liberdade. Porto: Textos Marginais, 1974.

GALEANO, E. Las palabras andantes. Montevideo: Ediciones Del Chanchito, 1993.

GIROUX, H. Recordando o legado da pedagogia do oprimido. In: FREIRE, A. M. A. et al. Pedagogia da libertação em Paulo Freire. São Paulo: Ed. da UNESP, 2001. p.113118.

HURTADO, C. N. El Pablo que yo conocí. In: Paulo Freire entre nosotros. Habana: Coletino Nacional Del CEEAL em Cuba, 1998. p.5-14.

LEITE, L. C. M. Encontro com Paulo Freire (entrevista). Educação e Sociedade, São Paulo, n. 3, p.47-75, maio 1979.

MELLO, T. Poemas preferidos: pelo autor e seus leitores. 2.ed. Rio de Janeiro:

Bertrand Brasil, 2002.

PAIVA, V. P. Educação popular e educação de adultos. São Paulo: Loyola, 1987.

PELBART, P. P. Poder sobre a vida, potência da vida. Lugar Comum, Rio de Janeiro, n.17, p.33-43, 2010.

PEREIRA, E. T. Cidadania, educação e inclusão: o caso brasileiro. In: CONGRESSO DA SOCIEDADE PORTUGUESA DE CIÊNCIAS DA EDUCAÇÃO, 6., 2003, Évora. Anais... Évora, Portugal: Universidade de Évora, 2003. p.04-05.

REGIS, M. O esquecido. Revista Isto É, São Paulo, p.67-71, 24 mar. 2000.

ROSAS, P. Depoimento I: Recife, cultura e participação (1950-64). In: EDUCAÇÃO e atualidade brasileira. 2. ed. São Paulo: Cortez, 2002. p.XLIX-LXXV.

SANTOS, B. S. Novos mapas culturais, novas perspectivas educacionais. Porto Alegre: Sulina, 1996.

TORRES, R. M. Os múltiplos Paulo Freire. In: FREIRE, A. M. A et al. Pedagogia da libertação em Paulo Freire. São Paulo: Ed. da UNESP, 2001. p.231-242. 